UNDERGRADUATE RESEARCH IN NATURAL AND CLINICAL SCIENCE AND TECHNOLOGY (URNCST) JOURNAL Read more URNCST Journal articles and submit your own today at: https://www.urncst.com

\title{
Science Atlantic 2020 Aquaculture \& Fisheries and Biology Conference
}

Kellie White, MSc [1]*, Russell H. Easy, PhD [2], Rebecca Gillis, BSc Student [1]

[1] Cape Breton University, Sydney, Nova Scotia, Canada, B1P 6L2

[2] Department of Biology, Acadia University, Wolfville, Nova Scotia, Canada, B4P 2R6

*Corresponding Author: kellie_white@cbu.ca

\begin{abstract}
Science Atlantic is a charitable association for scientists, university faculty, and science students that has been operating in Atlantic Canada since 1962. The association comprises 13 academic institutions and has a mandate to provide opportunities that foster and enrich students' academic experiences; support and inspire researchers, educators, and the broader scientific community; and represent a collective voice to address important regional science issues. In support of this mandate, the Science Atlantic Aquaculture \& Fisheries and Biology Committees host a joint annual conference that gives undergraduate students from the Atlantic region a chance to network as well as present and discuss their research with colleagues. Unfortunately, the 2020 conference slated for March 14-15 at Cape Breton University was canceled due to the Covid19 pandemic. The decision to cancel happened the day before the conference was set to begin. Because students were denied the opportunity to present their research we felt it was important to move forward with publishing the abstracts as a way of helping make up for this missed opportunity and to communicate their research results with the broader science community. The following are conference abstracts categorized into three parts: oral presentation in biology, oral presentation in Aquaculture \& Fisheries, and poster presentation
\end{abstract}

Keywords: undergraduate; research; biology; aquaculture; fisheries

Table of Contents

Oral Presentations in Biology

Oral Presentations Aquaculture and Fisheries

Poster Presentations in Biology

pg. A01-A06

pg. A06-A08

pg. A08-A16

\section{Conference Abstracts}

Note: These abstracts have been reproduced directly from the material supplied by the authors, without editorial alteration by the staff of the URNCST Journal. Insufficiencies of preparation, grammar, spelling, style, syntax, and usage are the authors.

\section{Oral Presentations in Biology}

Spatial and temporal structure of microbial eukaryote communities in two mudflats in the Upper Bay of Fundy Eke I. Kalu, BSc Student [1], Myriam A. Barbeau, PhD [1], Adrian Reyes-Prieto, PhD [1] [1] Department of Biology, University of New Brunswick, Fredericton, New Brunswick, Canada E3B $5 A 3$

Microbial eukaryotes are ubiquitous and occupy the vast majority of eukaryotic lineages. They perform fundamental roles in several ecologically vital processes including primary production, energy transfer, decomposition and biogeochemical cycling. Despite their extensive role in ecosystem functioning, our knowledge of the community dynamics of these microbes lag behind their prokaryotic counterparts. We characterized the natural dynamics of microbial eukaryote communities residing at four depths (the surface, $1 \mathrm{~cm}, 4 \mathrm{~cm}$ and $7 \mathrm{~cm}$ below the surface) in the sediments of two intertidal mudflats (Grande Anse and Pecks Cove in the Chignecto Bay, upper Bay of Fundy) in June to October 2019, using amplicon (hypervariable region V4) sequencing of the 18S rRNA gene. Additionally, we investigated relationships between community composition and sediment $\mathrm{pH}$, temperature and oxidation-reduction potential. We found that temporal variability of microbial eukaryote communities decreased with depth in mudflat sediments. Communities at the sediment surface differed significantly from those at $1 \mathrm{~cm}, 4 \mathrm{~cm}$ and $7 \mathrm{~cm}$ below the surface. Of the sediment properties measured, temperature 
UNDERGRADUATE RESEARCH IN NATURAL AND CLINICAL SCIENCE AND TECHNOLOGY (URNCST) JOURNAL Read more URNCST Journal articles and submit your own today at: https://www.urncst.com

best associated with changes in community composition among depths. Biotically, dinoflagellates and ciliates were the major contributors to the total dissimilarity between communities at various depths. This study provides a better understanding of the spatio-temporal dynamics and yet unexplored diversity of microbial eukaryote communities in sediments of mudflats in the upper Bay of Fundy. It also aids in the identification of microbial eukaryotes involved in major ecosystem processes in this highly productive and ecologically important system.

\title{
Change in occupancy and density of nesting atlantic puffins and razorbills on Machias Seal Island between 2011 and 2019 \\ Meredyth Elisseou [1], Heather L Major [1], Antony W Diamond [1] \\ [1] Department of Biological Science, University of New Brunswick Saint John, Saint John, NB E2K 5E2
}

At Machias Seal Island (MSI), nesting Atlantic Puffin (Fratercula arctica) populations are generally stable and estimated between 6,800 - 8,000 pairs. In contrast, the population of Razorbills (Alca torda) has been increasing. The purpose of our study was to determine whether the increasing Razorbill population is causing a change in the spatial distribution of Atlantic Puffins, pushing puffins out of more ideal nesting spots. We hypothesized that the larger, more competitive Razorbills outcompete puffins for nesting space, resulting in the movement of puffins to alternative areas of the island. Using data from Alcid censuses that occurred in 2011, 2015, 2016, and 2019, we assessed occupancy and density of puffins and razorbills in each of 1,753 surveyed quadrats. Using generalized linear models in an information theoretic approach, we found no changes in occupancy or density of either species. However, we note the short timespan (8 years) covered in our study and suggest that continued monitoring and analysis of changes in puffin and Razorbill occupancy and density.

\author{
Mechanism of skin colour evolution in the threespine stickleback \\ Morgan L. MacDonald, BScH Student [1], Anne C. Dalziel, PhD [1] \\ [1] Department of Biology, Saint Mary's University, Halifax, Nova Scotia, Canada B3H 3 C3
}

Often the most striking displays of colour in animals arise from interactions during mating. Nuptial colouration is exclusively associated with mating and typically functions in either female mate choice by signalling male quality or male competition by asserting dominance and possession of a territory. Colouration is the result of various chromatophores found within the integument of an animal. Changes in the distribution of chromatophores and their deposition of pigments over time is what causes seasonal colour change associated with nuptial colouration. The Threespine Stickleback (Gasterosteus aculeatus) is a ray finned fish found throughout the northern hemisphere that displays a large variation in nuptial colouration within the species. The white Threespine Stickleback, endemic to Nova Scotia, displays a pearlescent white colour during breeding season in contrast to the common Threespine Stickleback which is a dark green/brown colour. Although Threespine Sticklebacks are a model system for many evolutionary studies, the mechanisms involved in the evolution of the contrasting nuptial colouration of the white and common males are not well understood. The purpose of this study was to determine the cellular mechanisms underlying the differences in nuptial colouration of these ecotypes. In particular, I looked at both melanophore and iridophore coverage in the two dermal layers of stickleback chromatophores. My results show no statistical significance between the percent surface melanophore cover, surface iridophore cover, or deep iridophore cover, however the common males had significantly higher percent melanophore cover in the deep layer of the dermis.

Screening novel marine fungal strains for the production of polyunsaturated fatty acids, specifically eicosapentaenoic acid and arachidonic acid

Nicole M.H. Smith, BSc Student [1], Allison K. Walker, PhD [1], Jeremy J.R. Benjamin, PhD [2]

[1] Department of Biology, Acadia University, Wolfville, Nova Scotia, Canada, B4P 2R6

[2] Mara Renewables Corporation, Dartmouth, Nova Scotia, Canada, B2Y 4T6

The polyunsaturated fatty acids (PUFAs) eicosapentaenoic acid (EPA) and arachidonic acid (ARA) are important for human health. Alternate sources of these valuable PUFAs for human consumption are being sought to replace current, unsustainable, sources such as fish oil from wild-caught fish. Coldwater marine fungi show promise as a novel and potentially lucrative source of PUFAs, which could provide a renewable source of EPA and ARA. In collaboration with Mara Renewables Corporation in Dartmouth, Nova Scotia, this study established growth and screening methods for marine fungi. We isolated novel strains from the Atlantic Ocean, identified them by ITS rDNA barcoding and determined their fatty acid profiles. Marine fungal strains were grown in liquid cultures and screened for EPA and ARA production using fatty acid methyl esters (FAMEs) analyzed by gas-liquid chromatography. Of the 74 isolated marine fungi belonging to 25 genera, 
UNDERGRADUATE RESEARCH IN NATURAL AND CLINICAL SCIENCE AND TECHNOLOGY (URNCST) JOURNAL Read more URNCST Journal articles and submit your own today at: https://www.urncst.com

four Mortierella strains produced ARA and one Pythium strain (oomycete) produced both EPA and ARA, at commercially competitive quantities. Future research will target the isolation and screening of additional strains from these genera and scale up promising strains in bioreactors for optimization of growth and fatty acid production.

Characterizing the stress granule proteome of silvestrol treated U2OS cells

Stacia M. Dolliver, BSc Student [1] and Denys A. Khaperskyy, PhD [1]

[1] Department of Microbiology and Immunology, Dalhousie University, Halifax, Nova Scotia, Canada B3H $4 R 2$

Stress granules (SGs) are cytoplasmic phase-separated condensates of untranslated messenger ribonucleoproteins that form when eukaryotic cells are under stress. These granules are thought to modulate cellular stress responses; however, their molecular function remains elusive. Various stresses have induced SGs with differing composition and morphology, while the composition of SGs induced by the natural compound silvestrol remains unknown. Here, we utilized a proximity proteomics approach to characterise the composition of silvestrol-induced SGs in the human osteosarcoma cell line U2OS. Cells were transduced with a lentivirus vector carrying a doxycycline-inducible construct encoding the modified ascorbate peroxidase APEX2 fused to SG-nucleating protein G3BP1. SG formation was induced using $0.5 \mu \mathrm{M}$ silvestrol and proximity labeling was initiated with biotin-phenol and the APEX2 substrate hydrogen peroxide. The biotinylated G3BP1proximal proteins were purified using neutravidin agarose bead pulldown and liquid chromatography - tandem mass spectrometry (LC-MS/MS) was used to identify biotinylated proteins. Western blotting revealed that biotinylated proteins were present in the transduced samples and were captured in the neutravidin agarose pulldown. Following LC-MS/MS of the treated sample, 76 proteins were identified and 15 were found to be associated with SGs based on previous studies of sodium arsenite-induced SGs. Altogether, our observations reveal that APEX2 labelling and neutravidin pulldown can be used to isolate biotinylated proteins to examine protein-protein interactions in SGs. Further research will directly compare the composition of SGs induced by silvestrol and other stresses to identify proteins selectively recruited to silvestrol-induced granules and to provide important insights into SG functions with cellular stress responses.

Validation of environmental DNA (eDNA) applications/protocols for conservation of freshwater mussels Alasmidonta varicosa, Margaritifera margaritifera, and Lampsilis cariosa

Rebecca C. Button-Sibley, BSc Student [1]

[1] Department of Biology, Cape Breton University, Sydney, Nova Scotia, Canada B1P 6L2

Environmental DNA (eDNA) is an emerging tool that uses extracellular DNA or debris collected from environmental samples to detect species' presence without the need to catch, hear or see them. This method is particularly useful in aquatic habitats, where the presence of rare or low density taxa can be confirmed using small volumes of water and with minimal disturbance to sensitive environments. eDNA techniques have great application to conservation ecologists interested in monitoring the abundance and distribution of freshwater bivalves, a group currently under threat due to habitat loss and the introduction of non-native species. The aim of this research was to validate existing eDNA protocols for freshwater bivalve speciesAlasmidonta varicosa(SARA-listed)and Margaritifera margaritifera, and to develop an assay to expand eDNA use toLampsilis cariosa (SARA-listed). Analysis of DNA from aquatic environments involves water sampling and filtration, extraction of eDNA, and quantitative PCR to amplify the target DNA to determine species presence/absence. Preliminary results have confirmed the application of species specific primer/probes for each species; current work is now further validating these methods based on water samples from sites positive and negative for each target species. Ultimately, my research should help in the development of a robust and reliable protocol for using eDNA to sample unexplored aquatic environments in Cape Breton for the presence of endangered freshwater mussel species.

From the ground up: How groundcover plant diversity shapes snowshoe hare home ranges Gabrielle Riefesel, BSc Student [1], Isabella Richmond, MSc Candidate [1], Yolanda Wiersma PhD [1] [1] Department of Biology, Memorial University of Newfoundland, St. John's, Newfoundland, Canada A1C 5S7

In ecology, the relationship between individuals and their environment has often been determined by studying the spatial distribution of individuals. In a plant-herbivore system, knowledge on individual spatial distribution allows ecologists to better assess how dynamic variables such as plant species biodiversity and nutrient content influence herbivore space use. To better understand the relationship between the spatial distribution of the boreal forest keystone species, Snowshoe Hare (Lepus americanus), we have studied how the utilization distributions of individuals are affected by forage diversity and elemental 
UNDERGRADUATE RESEARCH IN NATURAL AND CLINICAL SCIENCE AND TECHNOLOGY (URNCST) JOURNAL Read more URNCST Journal articles and submit your own today at: https://www.urncst.com

composition across a study grid in central Newfoundland. We hypothesize that groundcover plant diversity will impact snowshoe hare home range utilization distributions. We predict that home range overlap will increase with increased plant diversity to support the requirement of a diverse diet to sustain weight, by creating a habitat that can support forage for prolonged periods due to varying plant physiologies and nutrient diversity. We calculated home ranges using radio telemetry data and used kernels to analyze the utilization distributions to determine the degree of overlap. We conducted groundcover vegetation surveys to determine a biodiversity index for 72 sample plots across a $500 \mathrm{~m}^{2}$ study area. We have calculated home ranges for 34 radio-collared hare between May and August in 2017, 2018 and 2019. The groundcover plant biodiversity plots identified 86 species. Home range analysis has shown a relationship to forage variation and quality. Our work highlights the importance of fine-scale variation in plant diversity and elemental composition as a driver for spatial habitat use by herbivores.

A tale of two (or three) mussels: DNA barcoding reveals one invasive, and additional previously undescribed species of unionids in Guanacaste, Costa Rica Baur, William [1], Easy, Russell H.[1], Cespedes Quesada, Rebeca [2], Arias, Sidey [2], Stewart, Don [1]

[1] Department of Biology, Acadia University, Wolfville, Nova Scotia, Canada B4P 2 R6

[2] Estación de Biología Marina, Universidad Nacional, Puntarenas

Three groups of morphologically distinct freshwater mussels (Family: Unionidae) were observed in Guanacaste, Costa Rica. Fourteen individual DNA samples were extracted and sequenced in the Stewart lab at Acadia University, using universal cytochrome oxidase subunit I primers, revealing invasive species Sinanodonta woodiana, and two unionid species that share $92.69 \%$ and $88.85 \%$ of similarity to native species Psorula profunda and Anodontites trigonus, respectively. The P. profunda relative is possibly among genus Nephronaias, which is undescribed on molecular databases such as GenBank. To confirm identification, phylogenic trees were constructed using MEGA7. Dioecious freshwater mussels typically exhibit mitochondrial DNA inheritance apart from conventional Strict Maternal Inheritance across metazoa: Doubly Uniparental Inheritance (DUI) propagates male-inherited mitochondria in male germ cells, and female-inherited mitochondria in male/female somatic cells, and female germ cells. DUI was detected in putative Nephronaias sp. using primers that only amplify male-only mitochondrial genomes within polymerase chain reactions. This research additionally discusses ecological and economic implications of $S$. woodiana establishment in Guanacaste and surrounding regions.

The effects of temperature on food consumption and growth rate in cunner (Tautogolabrus adspersus) Melina Watson BSc Student [1]

[1] Department of Biological Science, University of New Brunswick Saint John, Saint John, New Brunswick, Canada E2K 5E2

Temperature is an important environmental factor for fishes because, as ectotherms, their body temperature is determined by that of their surroundings. As such, winter is a critical time period for fishes, as they must contend with cold waters that slow their physiology, as well as poor food availability. A common strategy among many fishes to survive these winter challenges is winter dormancy. Winter dormancy is an inactive, sheltering state thought to involve reduced or no feeding. I investigated a winter-dormant fish, cunner (Tautogolabrus adspersus), to test the hypothesis that fasting is an obligate behavior of dormancy. I predicted that when cunner are exposed to temperatures below the dormancy threshold (the temperature at which they become inactive, $\sim 7.3^{\circ} \mathrm{C}$ ) they will cease feeding and that above the dormancy threshold the cunner will feed at a temperature-dependent rate. I exposed groups of cunner to various seasonal temperatures $\left(15^{\circ} \mathrm{C}, 12^{\circ} \mathrm{C}, 9^{\circ} \mathrm{C}, 6^{\circ} \mathrm{C}\right.$, and $\left.3^{\circ} \mathrm{C}\right)$ and observed their daily food consumption and growth rate over 4 weeks of acclimation at each temperature. Even when food was available below the dormancy threshold, cunner did not feed or fed at a very low level ( $<2 \%$ of body weight per day on average over the 4 weeks). Thus, appetite is greatly or even completely suppressed during dormancy. The major reduction in feeding was associated with a negative growth rate in dormant cunner, suggesting they use body fuel stores to sustain their energy demand. Fasting appears to be an obligate feature of winter dormancy, despite resulting in weight loss.

White et al. | URNCST Journal (2020): Volume 4, Issue 8

DOI Link: https://doi.org/10.26685/urncst.196 
UNDERGRADUATE RESEARCH IN NATURAL AND CLINICAL SCIENCE AND TECHNOLOGY (URNCST) JOURNAL Read more URNCST Journal articles and submit your own today at: https://www.urncst.com

\author{
Migratory stopover strategies of the white-rumped sandpiper (Calidris fuscicollis) \\ Jana Arseneault, BSc Student [1], Diana J. Hamilton, PhD [1], Cheri L. Gratto-Trevor, PhD [2], Julie Paquet, MSc[3] \\ [1] Department of Biology, Mount Allison University, Sackville, New Brunswick, Canada E4L 1E2 \\ [2] Prairie and Northern Wildlife Research Center, Science and Technology, Environmental Climate Change Canada, \\ Saskatoon, Saskatchewan, Canada S7N OX4 \\ [3] Atlantic Region, Canadian Wildlife Services, Environmental Climate Change Canada, Sackville, New Brunswick, \\ Canada E4L $1 G 6$
}

Many shorebirds such as Semipalmated Sandpipers (SESA, Calidris pusilla) and White-rumped Sandpipers (WRSA, Calidris fuscicollis) have adopted a long-distance migration strategy which is energetically costly and requires reliable access to high quality stopover sites to maximize survivorship. Although they are similar species, the White-rumped Sandpiper migrates farther each year and uses both "single -hop" and multiple stop strategies, whereas Semipalmated Sandpipers are predominantly a single stop species. In the Maritimes, SESA primarily stage in the Bay of Fundy, with smaller numbers present elsewhere, whereas WRSA are more common in coastal areas outside the Bay. Little is known about WRSA stopover ecology. To address this knowledge gap, we are comparing diet, fattening rate and stopover movements of WRSA and SESA along the Northumberland Strait, New Brunswick. In summer 2019 we captured WRSA and SESA at Petit-Cap, NB. We collected morphometric measurements and blood samples, and affixed radio tags to their backs to track movement in the region. Blood samples were used to measure plasma triglyceride levels, and index of fattening rate, and stable isotopes of $\mathrm{C}$ and $\mathrm{N}$ for diet determination. Results suggest that WRSA may fatten more quickly, move less between sites within the region, but have a similar stopover duration to SESA. They may need to gain more weight during their stopover to facilitate their longer migration. Most species of shorebirds are in decline. WRSA are one of the few that remains stable, so understanding their activities in this region will provide baseline data in advance of future declines.

The effect of salinity and photoperiod on the diel pattern of mummichogs (Fundulus heteroclitus) Emil Senathirajah, BSc Student [1]

[1] Department of Biological Science, University of New Brunswick Saint John, Saint John, New Brunswick, Canada E2K 5E2

The diel cycle of activity varies among fishes, with some species having a nocturnal pattern while others show a diurnal or a crepuscular pattern. Diel activity patterns can be plastic within individuals of a species, with shifts between patterns depending on extrinsic or intrinsic factors. The time of day where fish are the most active has important relationships to life traits such as growth, survivorship and fitness. Mummichogs (Fundulus heteroclitus) are ecologically important yet their diel cycle pattern is not well understood: some studies report a diurnal pattern while others report a nocturnal pattern. To resolve this discrepancy and better understand influences on the diel activity cycles of mummichogs, I investigated the effect of photoperiod and salinity on the day and night activity levels of mummichog using automated tracking software. Mummichogs were acclimated to full strength sea water (35ppt) or half strength sea water (17ppt) and their diel activity was measured after acclimation to a winter (10L:14D) photoperiod and then after acclimation to a summer photoperiod (12L:12D). Salinity and photoperiod had no significant effect on the diel pattern of mummichogs. Mummichogs do not appear to have diel variation in activity, rather remaining at a relatively constant activity level at all times.

Heritability of sexual traits in japanese medaka (Oryzias latipes)

Jolene McIsaac, BSc Student [1]

[1] Department of Biology, Saint Mary's University, Halifax, Nova Scotia, Canada B3H 3C3.

Phenotypic variation of sexual traits in Japanese Medaka (Oryzias latipes) have been observed in both wild populations and laboratory experiments. This variation has been correlated to differences in the social environment of the fish, namely the operational sex ratio. However, genetic variation can also play a role in phenotypic variation, which can be measured quantitatively and across generations to assess the heritability of the traits. A two-generation study was conducted to test the heritability of anal fin size, testis weight, and standard body length. Larger anal fins are beneficial for males in male-biased populations as they block sperm from competing males. Males can mate with multiple females in one day, making larger testis profitable as they are associated with a higher proportion of sperm being released. There has been experiments to support the idea that females chose their mates based on body size, also making this a favourable trait. It is presumed that these traits will be inherited because of the variation observed across populations and their potential to increase fitness for the individuals. This experiment also analyzed clutch and egg sizes for each female, as these relationships have been explored previously with conflicting results. Preliminary results show that female body size was not correlated to clutch size, but there

White et al. | URNCST Journal (2020): Volume 4, Issue 8

DOI Link: https://doi.org/10.26685/urncst.196

Page A5 of A17 
UNDERGRADUATE RESEARCH IN NATURAL AND CLINICAL SCIENCE AND TECHNOLOGY (URNCST) JOURNAL Read more URNCST Journal articles and submit your own today at: https://www.urncst.com

was intraclutch egg size variation. These results have not been fully explored, but further research will give us insights to the implications of this research.

\section{Oral Presentations Aquaculture and Fisheries}

Population abundance and structure in Yukon arctic grayling using genomics and close-kin mark-recapture Samuel JP. Prystupa, BSc Student [1], Greg R. McCracken, MSc [1], Robert. Perry, PhD [2], Daniel E. Ruzzante, PhD [1]. [1] Department of Biology, Dalhousie University, Halifax, Nova Scotia, Canada B3H 4R2

[2] Department of Environment: Fish and Wildlife Branch, Government of Yukon, Whitehorse, Yukon, Canada Y1A 4Y9

Two fundamental issues in conservation biology are the estimation of population abundance (census size) and effective size as well as their ratio. Here I aim to estimate the effective $\left(\mathrm{N}_{\mathrm{e}}\right)$ and census $\left(\mathrm{N}_{\mathrm{c}}\right)$ population sizes and population structure $\left(\mathrm{F}_{\mathrm{ST}}\right)$ of Arctic grayling inhabiting two independent systems in Yukon. We genotyped 1279 individuals collected from Lubbock and Blackstone systems at $n=39$ species specific microsatellite DNA markers. Collections from the Lubbock system consisted of 658 Adult individuals and 484 Young-of-the-year (YOY), collections from the Blackstone system were all YOY $(\mathrm{N}=137)$. We report on population structure and effective sizes and describe progress towards estimating population abundance in the Lubbock river using the Close kin mark recapture method. Population structure analysis found that within the 8 study sites corresponding to a creek or river, there were 6 distinct populations indicating no evidence of population structure as grouped sites were directly connected. Most populations were found to have Ne that corresponds to high genetic diversity. CKMR analysis estimated a $\mathrm{Nc}$ of 2713 for the Lubbock system from $\mathrm{N}_{\text {Mature }}=635$, $\mathrm{N}_{\text {Juveniles }}=87$, and median Parent-Offspring-Pairs $(\mathrm{POP})=40.72$. An $\mathrm{Ne} / \mathrm{Nc}$ ratio of 0.288 was estimated for the Lubbock system from $\mathrm{N}_{\mathrm{e}}=782$, and $\mathrm{N}_{\mathrm{c}}=2713$. Future work to improve the method should include obtaining age specific fecundity to improve CKMR estimate. This method will be used to inform management and conservation policy in streams, rivers, and lakes spanning the Yukon for native fish species.

A potential new seaweed harvesting industry in the Bay of Fundy: The red alga Vertebrata lanosa, aka the 'sea truffle' Emilie J. Knighton, BSc Student [1], David J. Garbary, PhD [1] [1] Jack McLachlan Laboratory of Aquatic Plant Resources, Department of Biology and Interdisciplinary Studies in Aquatic Resources, St. Francis Xavier University, Antigonish, Nova Scotia, CanaLda B2G 2 W5

The red seaweed Vertebrata lanosa is an abundant, obligate epiphyte on the brown alga Ascophyllum nodosum, the most abundant intertidal seaweed on rocky shores in Nova Scotia. The red alga has been collected in northern Europe and marketed as the 'Sea Truffle', where it is sold online for about Can \$1.50 per gram DW. From May to August 2019 we investigated the population biology and harvest sustainability of $V$. lanosa in the Bay of Fundy at 12 sites on Digby Neck and adjacent islands. At each site, three transects $(30 \mathrm{~m})$ were established parallel to the shore in the central part of the of the Vertebrata zone; these were randomly assigned one of three conditions: 1$)$ a destructively harvested transect (25 x $25 \mathrm{~cm}$ every 2-m along the transect), 2) a harvested sample to mimic a commercial harvester picking the Vertebrata by hand in a 1$\mathrm{m}$ band along the transect, and 3) an unharvested (control transect). For all three transects the following data were gathered at 1-m intervals: cover of $A$. nodosum, depth of $A$. nodosum and cover of $V$. lanosa. The hand-harvested sites were re-harvested on a monthly or bimonthly basis to examine population recovery. We estimate that hand-picking removes about $10 \%$ of the standing crop of Vertebrata, and that monthly harvesting during summer allows for full recovery of the population. We conclude that the 'Sea Truffle' provides the basis for a new, economically-viable and ecologically sustainable industry in southwestern Nova Scotia.

Drivers of roe taste in green sea urchin (Strongylocentrotus droebachiensis): A comparison of roe yield and amino acid profiles among urchins fed advanced formulated feeds

Elie Pellerin BSc Student [1], Gagnon, P.[1], Jacques, J.[1]

[1] Department of Ocean Sciences, Memorial University, St. John's, Newfoundland, Canada A1C 5S7

Green sea urchin (Strongylocentrotus droebachiensis) produces one of the finest roe (gonad) on top international seafood markets. The quick production of high volumes of high-quality green sea urchin roe has become one of the industry's main foci. Over the last few years, our Newfoundland based group carried out experiments and field surveys to help lay the foundation of a sustainable, provincial urchin roe industry based on the use of advanced formulated feeds, which bulk up 
UNDERGRADUATE RESEARCH IN NATURAL AND CLINICAL SCIENCE AND TECHNOLOGY (URNCST) JOURNAL Read more URNCST Journal articles and submit your own today at: https://www.urncst.com

urchin roe. We summarize ongoing research examining roe yield (gonadosomatic index; GSI) and amino acid (drivers of roe taste) profiles in Newfoundland green sea urchins maintained for a few weeks at three water temperatures $\left(1,3\right.$ or $\left.6{ }^{\circ} \mathrm{C}\right)$ in a low-flow containment system, and fed with either one fish- or one of two kelp-based versions of the feed. Preliminary analysis indicates that, as predicted, GSI of urchins fed with the fish-based diet peaked (to 19\%) at the highest temperature. The kelp-based diet with the highest proportion of kelp ingredients triggered the highest GSI increase, 198\%. However, alanine and glycine, which both contribute to roe sweetness (a desirable attribute), were most abundant in field (control) urchins, making up respectively $6 \%$ and $16 \%$ of the 20 amino acids examined. Valine, which contributes to roe bitterness, was most abundant in urchins fed with the fish-based diet, peaking at $7 \%$. Overall, results indicate that kelp-based diets outperformed the fish-based diet at an operationally suitable water temperature, which however may come at the cost of a less desirable roe taste.

Validating freezing in sea water as a method of pleopod preservation in american lobsters (Homarus americanus) Alaina M. Pyde, BSc Student [1], Rémy Rochette, PhD [1] [1] Department of Biology, University of New Brunswick, Saint John, New Brunswick, Canada E2L 4L5

The American lobster supports the most valuable fishery in Canada, this fishery is managed through an effort-based system rather than the more common quota-based system. One of the regulations of this fishery is when in the year it is legal to harvest lobsters, which is closely tied to their molt cycle. A lobster which has just molted is considered soft-shelled and is less valuable to the fishery. Monitoring their molt cycle is achieved by sampling and staging pleopods. However only freshly sampled pleopods could be used as preservation was thought to cause misidentification of the molt stage. In this study 318 pleopods where sampled and blindly staged twice prior to freezing in sea water, then again after freezing to quantify the error around stage assessments when pleopods are preserved by comparing the four assessments. It was found that the proportion of stages assessed did not significantly differ between pre-freeze and post-freeze, but the agreement between and within treatments was significant at all molt categories. By validating a preservation technic pleopods can be sampled and staged more readily and applied to future fishery regulations, which is crucial given the lobsters' changing ocean environment, and the important fishery that they support.

\section{Antifouling performance of augmented siloxanes on multiple species}

Emmerson R. Wilson, BSc Student [1], Katerina Basque, BSc Student [1], Amelia MacKenzie, BSc Student [1], Meaghan MacDonald, BSc Student [1], Russel Wyeth, PhD [1]

[1] Department of Biology, St Francis Xavier University, Antigonish, Nova Scotia, Canada, B2G 2W5

An environmentally friendly strategy for preventing biofouling is needed in the aquaculture industry, as more toxic methods are abandoned or prohibited. This study field tested siloxane-based fouling-release surfaces that aim to prevent or interfere with the adhesion of biofouling organisms. We sought to enhance their performance through the use of biodegradable surfactants (i.e. soap) as biocides that would not accumulate in the environment and silicone oil to further decrease attachment strengths. Antifouling performance was assessed by comparing percent cover of various local biofouling species at approximate weekly intervals at two locations. The most prominent species were the hydroid Ectopleura larynx, colonial ascidian Botrylloides violaceusand solitary ascidian Ciona intestinalis. We found silicone oil delayed biofouling by about 3 to 4 weeks depending on location, and reduced total biofouling by approximately $60 \%$, biofouling by $E$. larynxby about $50 \%$ and $C$. intestinalis by $70 \%$. In addition, silicone oil significantly reduced the attachment strength of ascidians. There was also a smaller but still significant reduction of about $7 \%$ in biofouling by hydroids on siloxane-based coatings treated with biodegradable surfactants. In order to consider silicone oil as a potential antifouling treatment, environmental impacts of use at a commercial scale should be investigated. Furthermore, methods for the application of silicone oil in a commercial setting will need to be designed.

\section{Size selective mortality at sea: Scale growth analysis of Salmo salar in 3 Atlantic Canadian rivers Erin Francheville [1] [1]Department of Biology, St Francis Xavier University, Antigonish, Nova Scotia, Canada, B2G 2W5}

Size selective mortality at sea in Atlantic salmon, Salmo salar, has been a growing area of concern as researchers attempt to explain the reason for population decline and lowering return rates to spawning rivers. The paper "Retrospective growth analysis of Atlantic salmon" (Friedland, Moore, Hogan, 2009) demonstrated that mortality in the Atlantic salmon population 
UNDERGRADUATE RESEARCH IN NATURAL AND CLINICAL SCIENCE AND TECHNOLOGY (URNCST) JOURNAL Read more URNCST Journal articles and submit your own today at: https://www.urncst.com

was occurring at sea. In order to investigate the existence of a significant correlation between river size and mortality at sea, scale samples from smolts and returning adults (1SW and 2SW age at maturity) from 3 index rivers were analyzed. The 3 Atlantic Canadian rivers are the Northwest Miramichi river, the Nashwaak river and the LaHave river. Where available, up to a maximum of 100 samples each of smolt, and adult (1SW and 2SW age groups separately) scales from the following years were analyzed: 1998, 1999, 2000, 2001, 2002. Scale measurements were made using (TPS) image analysis software. All scale growth data was collected along the longest radial axis of the scale and varied depending on the life stage of the particular scale. Data from these measurements was collected in the form of xy coordinates. In this way, size distribution graphs can be created to reveal what size salmon is demonstrating the highest return rates. Using MS Excel spreadsheets these points can be converted to linear distances and recorded along with each fish's life history information. Determining advantageous smolt size for returning salmon is crucial for further research aiming to understand mortality at sea.

\section{$\underline{\text { Poster Presentations in Biology }}$}

Does differential maternal investment exist within european starling (Sturnus vulgaris) clutches? Alexa Tymkiw, BSc Student [1]

[1] Biology Department, Saint Mary’s University, Halifax, Nova Scotia, Canada B3H 3 C3

Most passerine species are known to incubate their altricial young such that offspring may hatch asynchronously in order to provide better opportunity for entire brood survival and success. In order to accommodate this asynchronous hatching, maternal passerines can adopt one of two strategies to manipulate brood size through egg mass of the last-laid egg. Brood survival strategy will signify increased maternal investment in the last-laid egg, suiting the availability of ample resources in the breeding season and allowing increased competitive ability of the weakest offspring. Brood reduction strategy is useful when resources are unpredictable and implies decreased maternal investment in the last-laid egg so that it may act as an insurance policy based on the resources available. Because of fluctuating resource availability throughout the breeding season, it is possible that maternal investment may be differential between earlier clutches and later clutches. I studied maternal investment strategies within a population of European starlings over 5 years, collecting egg masses for 117 early brood clutches, 13 intermediate brood clutches and 76 late brood clutches. Variation in egg mass between the last-laid egg of a clutch and the average of the other eggs in the clutch was assessed. Last-laid egg masses were found to be significantly smaller for only early brood clutches. Therefore, it appears that European starlings employ a brood reduction strategy; that is, mothers lay smaller last-laid eggs in order to allow for the adaptive consumption of fluctuating resources throughout the breeding season.

\section{Effects of sexual selection and sexual conflict due to operational sex ratios on female Japanese medaka (Oryzias latipes) behaviours \\ Amanda L. Gove, BSc Student [1] \\ [1] Biology Department, Saint Mary’s University, Halifax, Nova Scotia, Canada B3H 3 C3}

Operational sex ratio (OSR) is the ratio of sexually active males to fertilizable females in a population. It is used to predict sexual conflict behaviours in species, specifically on which mate will have reproductive success and which will have fitness cost. Sexual conflict is an evolutionary theory within the framework of sexual selection. Sexual selection can be broken down into two mechanisms for mating purposes, competition and choice. There exist three characteristics that influence the way species behave in regard to reproduction: sexual conflict, sexual selection, and OSRs. The goal of this research is to determine how various OSRs influence the behaviour of female Japanese medaka (Oryzias latipes). During the experiment, observations were recorded on female medaka that were in two-minute increments for three rounds of 24 tanks, each tank had a mixture of an OSR, male:female ratio of $0.5,1,2$, and 5. Data was recorded for six different behaviours from the observed female. These behaviours included: the observed female being chased by a male or female, the observed female chasing a male or female, refusal, and interruption. The behaviours were categorized into either sexual conflict or sexual selection behaviours. Refusal, chases male, and chased by females are the traits of sexual conflict as the goal is for the species to mate and if females are not accepting the male's courtship, it leads to conflict. Whereas, chases female, chased by female, and interruption are sexual selection behaviours, specifically female-female competition. 
UNDERGRADUATE RESEARCH IN NATURAL AND CLINICAL SCIENCE AND TECHNOLOGY (URNCST) JOURNAL Read more URNCST Journal articles and submit your own today at: https://www.urncst.com

Exploring the effects of blue light and abscisic acid on leaf surface wax and methane emissions from canola plants grown under sterile conditions

Cassidy-Rae L. Creelman [1], BSc Student, Mirwais M. Qaderi, PhD [1]

[1] Department of Biology, Mount Saint Vincent University, Halifax, Nova Scotia, Canada B3M 2J6

Methane $\left(\mathrm{CH}_{4}\right)$ is the second important greenhouse gas after carbon dioxide $\left(\mathrm{CO}_{2}\right)$, with a global warming potential of nearly 34 times higher than $\mathrm{CO}_{2}$. Many studies have investigated the precursors of plant-derived $\mathrm{CH}_{4}$, but few of them have grown plants under sterile conditions. It is important to measure $\mathrm{CH}_{4}$ that is originated from plants and determine factors that affect its emission. Our objective was to examine the combined effects of blue light and abscisic acid (ABA) on $\mathrm{CH}_{4}$ emission and epicuticular wax of plants under sterile conditions. We hypothesized that blue light and ABA increase leaf surface wax, which leads to increased $\mathrm{CH}_{4}$ emission. In this study, canola (Brassica napus L. cv. $6056 \mathrm{CR}$ ) plants were grown at three levels of blue light $\left(0,4\right.$ and $\left.8 \mathrm{~mW} \mathrm{~cm}^{-2}\right)$ and supplied with two concentrations of $\mathrm{ABA}\left(0\right.$ and $\left.26.4 \mathrm{mg} \mathrm{L}^{-1}\right)$. Four-day-old seedlings were transferred to the sterilized jars with agar. Half of the jars were supplied with ABA. The jars were randomly assigned to one of twelve treatments (each with three replications) and plants were grown for 14 days. Then, $\mathrm{CH}_{4}$ emissions were measured in gas samples from the jars and incubated leaves. For wax analysis, extra plants were grown under the same experimental conditions. Overall, this study revealed that exogenous $\mathrm{ABA}$ increased $\mathrm{CH}_{4}$ emissions, measured from the jars, but decreased total biomass of the plants. Leaf surface wax was relatively higher with the ABA application. In conclusion, stressed plants emitted more $\mathrm{CH}_{4}$ than non-stressed plants under sterile conditions.

Sub-lethal effects of mercury on leach's storm-petrel Safyha V.J. Bryan, BSc Student [1], Mark Mallory, PhD [1], Nelson O'Driscoll, PhD [2], Dave Shutler, PhD [1]

[1]Department of Biology, Acadia University, Wolfville, Nova Scotia, Canada B4P 2R6

[2]Department of Earth \& Environmental Sciences, Acadia University, Wolfville, Nova Scotia, Canada B4P 2R6

Mercury occurs in food webs both naturally and from human inputs. Methyl mercury is toxic, and bioaccumulates and biomagnifies in food webs, particularly marine ones. Leach's storm-petrels are an abundant seabird in the North Atlantic, and their diets and tissues can have high levels of mercury. We tested for sub-lethal associations among blood mercury, feather mercury, haemoglobin, and blood glucose in breeding storm-petrels. Preliminary results from a sample of 26 birds suggested blood mercury concentrations were weakly associated with levels of haemoglobin $(r=-0.28, \mathrm{p}=0.27)$ and glucose $(\mathrm{r}=0.23$, $\mathrm{p}=0.17)$. Similarly, feather mercury was not a significant predictor of blood glucose $(r=0.13, \mathrm{p}=0.52)$ or haemoglobin $(\mathrm{r}=$ $-0.03, \mathrm{p}=0.88$ ). However, we detected higher mercury in storm-petrel feathers than in blood, consistent with predictions that birds shunt toxic heavy metals to inert feather tissues during moulting, reducing body burdens.

The effect of exercise on thermal tolerance of brook charr (Salvelinus fontinalis)

Emma M. Traynor, BSc Student [1], James D. Kieffer, PhD [1]

[1] Department of Biology, University of New Brunswick, Saint John, New Brunswick, Canada E3B 5A3

This study examined whether exercise influences the acute thermal tolerance $\left(\mathrm{CT}_{\mathrm{Max}}\right)$ in brook charr (Salvelinus fontinalis). To address this, fish were assigned to one of following four groups: (i) control (no thermal or exercise stress); (ii) exercise only; (iii) thermal stress only (thermally stressed); and (iv) exercise followed by the thermal stress. In addition to examining the thermal tolerance, I also took small blood samples from the fish to measure stress parameters (plasma lactate and glucose) in fish assigned to the different treatment groups. Overall, the acute thermal tolerance was not different between fish exposed to the thermal stress only and the fish that were exposed to exercise stress prior to the thermal challenge. However, the levels of blood lactate and glucose were highest in trout exercised prior to the thermal stress. These findings show that even though there are no differences in the thermal tolerance between groups, there are additional physiological effects in fish exercised prior to the thermal stress. 
UNDERGRADUATE RESEARCH IN NATURAL AND CLINICAL SCIENCE AND TECHNOLOGY (URNCST) JOURNAL Read more URNCST Journal articles and submit your own today at: https://www.urncst.com

Predator avoidance behaviour of grass shrimp in relation to varying salinity

Cassidy Smith, BSc Student [1], Christina MacLean, BSc Student [1], Brittney Gurney, BSc Student [1], Barb Glassey, PhD

[1], Kellie White, MSc [1]

[1] Department of Biology, Cape Breton University, Sydney, Nova Scotia, Canada B1M 1A2

Increased heavy rainfall events and increasing sea level associated with climate change will likely impact salinity levels within estuaries. The ability to detect and respond to predators may be affected by these changes in salinity. We studied the impact of varying salinity concentration on predator detection and avoidance in the estuarine grass shrimp Palaemonetes vulgaris. We did so by comparing behavioral responses of undisturbed shrimp to shrimp exposed to chemical alarm cues from injured conspecifics and shrimp exposed to simulated physical predation within fresh water and brackish water treatments $(0.4 \mathrm{ppt}$ and $10 \mathrm{ppt}$ respectively). There was a significant decrease in active behaviours in relation to predation threat level for both salinity treatments. We also saw a trend for decreasing social behaviour in relation to threat level for both water treatments. There was a significant interaction between predation threat and salinity level for backward thrust, with a greater frequency of backward thrust observed in brackish water compared to in fresh water in response to chemical threat. This may be an indication that low salinity impairs grass shrimps ability to detect and respond to chemical alarm cues. Finally, we observed a trend for increasing aggregation behavior in brackish water; no clear trend was observed in fresh water. Our results suggest that reduced salinity concentrations may impair a grass shrimp's ability to detect and actively avoid predators.

\section{Development and analysis of an in vitroco-culture hepatic fibrosis model}

Madison C. Kropp, BSc Student [1], John P. Frampton, PhD [2], Jonathon Tjong, PhD Student [2], Rishima Agarwal, MASc [2], Nicky Tam, MASc Student [2], Kristen Ko, MD Student [3]

[1] Department of Biochemistry and Molecular Biology, Dalhousie University, Halifax, Nova Scotia, Canada B3H 4R2

[2] School of Biomedical Engineering, Dalhousie University, Halifax, Nova Scotia, Canada B3H 4R2,

[3]School of Medicine, Dalhousie University, Halifax, Nova Scotia, Canada B3H 4R2

One in four Canadians may be affected by liver disease at some point in their life. Liver fibrosis is a major component of many of these diseases, potentially leading to cirrhosis and dysfunction in the long term. Fibrosis is the abnormal formation of scar tissue consisting of fibrillar extracellular matrix (ECM) as a result of repeated injury or chronic disease, and the primary contributor to this ECM deposition are hepatic stellate cells (HSCs). Here, we show the development of an in vitroco-culture hepatic fibrosis model to examine how HSCs influence the viability and function of healthy hepatocytes. The hepatocytes are biopatterned (by depositing cells on a surface with sub-millimeter spatial resolution) using an aqueous twophase system (ATPS) comprising of equilibrated 5\% polyethylene glycol and $6.4 \%$ dextran to form organoids. These organoids are then surrounded by HSCs. The cells are subsequently treated with methotrexate, a pro-fibrotic compound that initiates the activation of HSCs that then leads to fibrosis. The organoids formed using an ATPS demonstrate increased proliferation and survival than seeded cells. This growth is further increased when using an equilibrated (thermodynamically stable) APTS as the stacking within the organoid is more uniform. This co-culture model could be used in drug development to study the effects that novel compounds have on activating fibrotic cells and healthy hepatic cells, as well as to explore disease mechanisms underlying various liver diseases.

Strength or speed: What makes rapid evolution possible?

Mei Shimizu, BSc Student [1], Stevan A. Springer, PhD [1]

[1] Department of Biology, University of Prince Edward Island, Charlottetown, Prince Edward Island, Canada ClA 4P3

Proteins that control conflicting interactions, like the receptors of hosts and viruses, evolve faster than anything else. But does this mean that interaction proteins are driven by unusually strong selection? Maybe not. The answer depends on how new functions arise by mutation. If new adaptive mutations are rare, strong selection would be the only way to explain rapid evolution. But if adaptive mutations are common, then a protein could evolve fast even if selection wasn't unusually strong. We'll use our method of measuring the effects of mutations to simulate evolution when adaptive changes are rare or common and reconcile the two existing measures of protein evolution: strength (s) and speed (dN/dS). Biologists measure the strength of selection by looking at changes in allele frequency. The more abundant a mutation gets from one generation to the next, the stronger the force of selection (s). Speed is measured with a method called dN/dS. dN is the rate of amino-acid substitution and dS is the rate of non-functional change. We infer rapid protein evolution when we see many functional changes for each non-functional change. Our work will simulate evolution at specific selection intensities (s) by evolving 
UNDERGRADUATE RESEARCH IN NATURAL AND CLINICAL SCIENCE AND TECHNOLOGY (URNCST) JOURNAL Read more URNCST Journal articles and submit your own today at: https://www.urncst.com

proteins through a series of changes when new adaptive mutations are rare and when they are common. We expect that weak selection could drive rapid evolution when adaptive changes are common. Thus, interacting proteins could evolve so fast because of the changes available to them and not the intensity of selection acting on them.

Prionace glauca as ecosystem indicators for climate change on the Scotian shelf Emily Sklar, BSc Student [1]

[1] Department of Biology, Dalhousie University, Halifax, Nova Scotia, Canada B3H 4 R2

The blue shark (Prionace glauca) is the most heavily targeted shark in the world. Juvenile females are important for the species' resilience to overfishing. These females aggregate on the Scotian Shelf in the summer as primary productivity increases, then depart as winter approaches. As the Scotian shelf is warming approximately twice as quickly as the average world ocean, I predict a shift in the sharks' seasonal residence based on their temperature preferences $\left(12-20^{\circ} \mathrm{C}\right) . \mathrm{I}$ expect that juvenile females will arrive earlier when water warms earlier, stay later when temperatures remain favourable later, and mean residence time will be longer in years when temperature is optimal longer. I analyzed a time series of acoustically tagged juvenile female blue sharks occupying the Scotian shelf. Ocean Tracking Network (OTN) and associated scientists tagged 117 sharks between 2013 and 2019. Detections were retrieved from the OTN Halifax Line, spanning the width of the shelf. Temperature data came from OTN and DFO glider fleets. Linear regression analysis shows fewer sharks returning to the Scotian shelf after being tagged the previous year, suggesting increased mortality. ANOVA results suggest that sharks remain on the Scotian shelf later each year. Annual temperature trends are being examined to determine whether a correlation between temperature and seasonal residence exists. Results will help develop dynamic management plans to advise fisheries and protect the species. Results may be used towards an "index", where timing and duration of seasonal presence of blue sharks can be used as an indicator for ecosystem health.

\section{Investigating the effect of arbuscular mycorrhizae on Crocanthemum canadense (L.) Britt. (Cistaceae) propagated in tissue culture Kendra Sampson, BScH Student [1], Robin Browne, PhD [2], Allison K. Walker, PhD [1], and Rodger C. Evans, PhD [1] [1] Department of Biology, Acadia University, Wolfville, Nova Scotia, Canada B4P 2 R6 \\ [2] K.C. Irving Environmental Centre and Harriet Irving Botanical Gardens, Acadia University, Wolfville, Nova Scotia, Canada B4P $2 P 8$}

Crocanthemum canadense (L.) Britt. (Cistaceae), Rockrose, is a small perennial herb found in Eastern North America sand barrens. It is classified as critically imperiled in Nova Scotia under the Nova Scotia Endangered Species Act. Nova Scotia Rockrose populations continue to decline; recent counts estimate only 5000-5500 plants remain. To better understand Rockrose biology, we've analysed symbiotic mycorrhizal associations among native Nova Scotia populations. Recent research from our group has documented the presence of arbuscular mycorrhizal fungi (AMF) within Rockrose roots of plants in their native habitat; the present study is the first study to focus primarily on the benefits of this symbiotic relationship between Rockrose and AMF. AMF improve plant water uptake as well as nutrients uptake (phosphorus and nitrogen) by the plant. In return, they rely on the plant as a host and carbon source. Using a greenhouse trial with varying percentages of AMF inocula, we determined how AMF would affect the growth of Rockrose plants propagated from tissue culture. The 1:25 inoculum had the most significant effect on the height of the shoots $(\mathrm{cm})$ while the 1:50 inoculated plants had the largest root mass $(\mathrm{g})$. The identity of AMF in the roots and the inoculum was determined using rDNA barcoding. A species of AMF sister to Funneliformis mosseae was identified. This research will potentially aid in the conservation and restoration of this critically imperiled species by further understanding beneficial soil fungi, an understudied component of the sand barrens habitat.

Comparing the effectiveness of protein coding gene regions and the ITS region as DNA barcode markers for specieslevel identification of Penicillium and Aspergillus fungal isolates

Hui Ting Po, BSc Student [1], Christopher A. Gray, PhD [1,2], John A. Johnson, PhD [1,2]

[1] Department of Chemistry, University of New Brunswick, Saint John, New Brunswick, Canada E2L4L5

[2] Department of Biological Sciences, University of New Brunswick, Saint John, New Brunswick, Canada E2L4L5

Penicillium and Aspergillus are important genera of fungi that produce natural products with potential applications in food, agricultural, biotechnological and pharmaceutical industries. Accurate species identification allows researchers to collate and access important information about the biochemistry, health risks or ecological implications attached to these fungi. 
UNDERGRADUATE RESEARCH IN NATURAL AND CLINICAL SCIENCE AND TECHNOLOGY (URNCST) JOURNAL Read more URNCST Journal articles and submit your own today at: https://www.urncst.com

Traditionally, morphological examination was used to identify fungal species but, since 2012, DNA barcoding using the Internal Transcribed Spacer (ITS) region has become more widely used despite there being limitations associated with the identification of Penicillium and Aspergillus species. In these two genera, protein coding gene regions, e.g. benzoate 1,2-dioxygenase alpha subunit (BenA) or calcium-modulated protein $(\mathrm{CaM})$, may be more effective DNA barcode markers than the ITS region. In the present study, we therefore compare whether protein coding gene regions are more effective than the ITS region at identifying species within these two prolific genera. Here we sequenced DNA from fungal endophytes using both the ITS region and protein coding region (BenA or $\mathrm{CaM}$ ) and performed species identification using the Basic Local Alignment Search Tool (BLAST) in GenBank. Our results show that BenA is more effective than ITS at identifying Penicillium species but CaM and ITS are similarly effective when identifying Aspergillus species. Although protein coding genes are more effective than the ITS gene at identifying highly speciose fungi, there are more ITS sequences than protein coding sequences as well as many misannotated sequences that exist in GenBank thus it is recommended that caution be taken when performing species identification.

Changing habitat use by two odontocete cetacean species in Newfoundland and Labrador waters Keeley A. Blanchard, BSc Student [1], Dr. Jack Lawson, PhD [2]

[1] Department of Biology, Memorial University of Newfoundland, St. Johns, Newfoundland, Canada A1C 5S7

[2] Department of Marine Mammals, Fisheries and Oceans Canada, St. Johns, Newfoundland, Canada A1C 5X1

To facilitate the conservation and protection of marine mammals, information on their distribution and habitat use is crucial. An initial approach to understand the relationship between a species and its habitat is to create spatial density maps that incorporate information on temporal changes across seasons and longer time spans. Long-term sighting data collections can provide the data needed to construct such maps, particularly if systematic surveys were used to collect them. Sighting data of white-beaked dolphins (Lagenorhynchus albirostris) and long-finned pilot whales (Globicephala melas) for the period 1955-2017 off the coast of Newfoundland and Labrador were input to a Geographic Information System to examine spatial occupancy patterns across seasons and years. These data span a period when there has been a decline in the number of pilot whales sighted in Newfoundland and Labrador waters, in contrast to a large increase in the number of white-beaked dolphin sightings in the same area. These changes in the relative abundance of these animals cannot be explained by reproduction alone, so it is likely these animals changes their occupancy in these areas. Spatial and temporal distribution maps show changes in their habitat use since 1975, with notable alterations more recently (post 1990 for pilot whales and post-2000 for the dolphins).

\author{
Abundance of actinomycetes on decomposing pine ectomycorrhizae \\ Kaylee Boyle, BSc student [1], Gavin Kernaghan, PhD [1] \\ [1] Department of Biology, Mount Saint Vincent University, Halifax, Nova Scotia, Canada B3M 2J6
}

Actinomycetes are filamentous bacteria that make up one of the largest groups in the domain Bacteria. They are found everywhere, although mainly in the soil. Actinomycetes are well known as producers of important secondary metabolites, such as two-thirds of all known antibiotics, other pharmaceutical compounds, fungicides, and pesticides. For this reason, they are highly sought after as new sources of pharmaceuticals and bioactive agents. Actinomycetes are important in the soil as nitrogen fixers and efficient decomposers of chitin, keratin, and lignocellulose. Actinomycetes are also found in association with ectomycorrhizae, and may be involved in tripartite plant-fungal-bacterial symbioses. However, their ability to digest chitin and lignocellulose may also allow them to digest mycorrhizae. The objective of this study was to monitor actinomycete abundance after severing ectomycorrhizal root systems, as an increase in actinomycetes over time would be indicative of a role in mycorrhizal decomposition. Actinomycetes associated with ectomycorrhizae formed by Cenococcum geophilum on the roots of Pinus strobus were quantified by real-time quantitative PCR (qPCR) at different time points over a 15-month post-disturbance period. Actinomycete abundance appears to be highest in the undisturbed samples, suggesting that actinomycetes have a closer association with healthy, rather than decomposing ectomycorrhizae.

Insights into the recruitment of deep-water corals on the continental slope: Implications for conservation Graeme T. Guy, BSc Student [1], Anna Metaxas, PhD [2]

[1] Department of Biology, Dalhousie University, Halifax, Nova Scotia, Canada B3H 4R2

[2] Department of Oceanography, Dalhousie University, Halifax, Nova Scotia, Canada B3H 4R2

Deep-water corals provide habitat for commercially important fish species and other invertebrates. Because these corals can be slow to recover from impacts such as ground fishing, due to their slow growth and long life span, they have been selected

White et al. | URNCST Journal (2020): Volume 4, Issue 8

DOI Link: https://doi.org/10.26685/urncst.196

Page A12 of A17 
UNDERGRADUATE RESEARCH IN NATURAL AND CLINICAL SCIENCE AND TECHNOLOGY (URNCST) JOURNAL Read more URNCST Journal articles and submit your own today at: https://www.urncst.com

as a conservation priority by the Department of Fisheries and Oceans (DFO) in Atlantic Canada. The Northeast Channel Coral Conservation Area (NECCCA) and the Corsair and Georges Canyons Coral Conservation Area (CGCCCA) are two fisheries closures designed to protect the densest known aggregations of deep-water coral species, Primnoa resedaeformis and Paragorgia arborea, in Atlantic Canada. In June 2019, the Remotely Operated Vehicle 'ROPOS' was used to collect five video transects in unexplored areas of the Scotian Shelf, ranging between 138 and $1166 \mathrm{~m}$ in depth. The size, distribution, and abundance of corals $P$. resedaeformis and $P$. arborea were studied from these video recordings. $P$. resedaeformis and $P$. arborea were recorded at high densities within the CGCCCA, at 248 colonies $100 \mathrm{~m}^{-2}$ and 9.7 colonies $100 \mathrm{~m}^{-2}$, respectively. P. resedaeformis was also observed at densities of 50 colonies $100 \mathrm{~m}^{-2}$ outside of the NECCCA. The presence of numerous small colonies $(<10 \mathrm{~cm})$ and analysis of the size frequency distributions of coral colonies suggests continuous, high recruitment rates for $P$. resedaeformis in the northeast section of the CGCCCA (maximum density of colonies <10 cm: 8.3 per $\mathrm{m}^{2}$ ), as well as outside the NECCCA (maximum density of colonies $<10 \mathrm{~cm}^{2} 9.97$ per $100 \mathrm{~m}^{2}$ ). The high density of recruits and relatively small number of large colonies of $P$. resedaeformis suggests high disturbance outside the NECCCA and provides evidence that an extension of the boundaries is appropriate.

Flagellin glycosylation in a plant growth-promoting bacterium

Hannah B. Ralph, BSc Student [1], Cheryl Patten, PhD [1]

[1] Department of Biology, University of New Brunswick, Fredericton, New Brunswick, Canada E3B 5A3

Post-translational glycosylation of flagellin, the major subunit of the flagella filament, determines host plant permissiveness for infection by phytopathogenic Pseudomonas syringae strains. The mechanism by which the plant growth-promoting bacterium P. syringae GR12-2 evades the plant defense response is currently unknown, however, flagellin glycosylation may be involved. Comparative sequence analysis of the flagella biosynthetic loci of $P$. syringae GR12-2 and $P$. syringae pathovar genomes suggested flagellin glycans may be different among the strains. We aimed to determine the function of the predicted glycosyltransferases and glycan biosynthetic enzymes in flagellin glycosylation in P. syringae GR12-2. Mutants were constructed by deleting predicted genes for glycosyltransferases, a glycan synthesis enzyme, and the flagellin gene. We confirmed the mutations by polymerase chain reaction and compared generation times among strains. We purified the flagellin, quantified it using the Bradford assay, and then visualized it via polyacrylamide gel electrophoresis with both Coomassie brilliant blue and glycoprotein straining. A protein with the expected molecular mass of glycosylated flagellin was present in the wild-type strain but absent in the flagellin mutant. Proteins with the predicted size of de-glycosylated flagellin were observed in the glycosyltransferase mutants and the glycan synthesis mutant, which supports our hypothesis that these genes are essential for flagellin glycosylation. Next, we will inject the flagellin proteins purified from all strains into tomato and tobacco plants to assess induction of the plant defense response. This research is a first step toward understanding the role of flagellin glycosylation in host plant permissiveness to colonization by beneficial bacteria.

\section{Developing a canine genetic testing program at the Atlantic Veterinary College: Pilot study on disease susceptibility loci in labrador retrievers \\ Alycia Cooper, BSc Student [1], Jeremy Lightfoot [2], Cody Bourque [2], Marco Duguay [2], Blanca Esparza [3], Sunny \\ Hartwig [3] \\ [1] Department of Biology, University of Prince Edward Island, Charlottetown, Prince Edward Island, Canada C1A 4P3 \\ [2] Atlantic Veterinary College, University of Prince Edward Island, Charlottetown, Prince Edward Island, Canada C1A 4P3 \\ [3] Department of Biomedical Sciences, Atlantic Veterinary College, University of Prince Edward Island, Charlottetown, Prince Edward Island, Canada C1A 4 P3}

Canine genetic testing for disease susceptibility loci provides invaluable guidance for dog breeders, enabling them to eliminate known disease carriers from breeding programs, and thereby avoid generating affected progeny. Notwithstanding, many breeders forgo genetic testing due to prohibitively high costs and long turnaround times associated with these tests, despite the potentially catastrophic risks associated with breeding dogs of unknown genotypes. Our overall objective is to develop and validate a rapid turnover, cost-effective canine genetic testing program at the Atlantic Veterinary College. To this end, we are conducting a pilot study to develop and validate a complete genetic test panel for heritable diseases in Labrador retrievers, including (1) exercise-induced collapse, (2) progressive rod-cone degeneration, and (3) degenerative myelopathy, which are each associated with a single nucleotide polymorphism (SNP) at the disease locus, and (4) centronuclear myopathy which is associated with a short interspersed nuclear element (SINE) insertion. First, plasmids were designed containing wild type or mutant alleles of each gene of interest and served as genotyping controls. Then, polymerase chain reaction-restriction fragment length polymorphism (PCR-RFLP)-based tests were designed for SNP and SINE typing. Following PCR-RFLP test 
UNDERGRADUATE RESEARCH IN NATURAL AND CLINICAL SCIENCE AND TECHNOLOGY (URNCST) JOURNAL Read more URNCST Journal articles and submit your own today at: https://www.urncst.com

optimization with plasmid DNA controls, approximately 300 canine buccal swabs obtained from Labrador retriever breeders were tested. Further studies will include validating our blinded test results with results previously obtained by breeders. Ultimately, results from this study will support a grant application to develop a full genetic testing program.

Changes in flower shape coincide with reduced visitation in spurred gentian (Halenia deflexa) Róisín M. Kierstead, BSc Student [1], Emily J. Austen, PhD [1] [1] Department of Biology, Mount Allison University, Sackville, New Brunswick, Canada E4L 1E2

Spurred gentian (Halenia deflexa) is named after the nectar spurs (i.e. nectar-storing appendages) that adorn its flowers. Nectar spurs generally affect the mechanical fit between plants and their pollinators because they restrict nectar access to animals with long-tongues or strong mouth parts. Nectar spurs are therefore an important floral trait that can shape species' pollination ecology. Halenia deflexa's pollination ecology, however, has not been documented and it is unclear whether the species has any legitimate insect pollinators. I aimed to determine the primary pollinators of $H$. deflexa. During summer 2019, I observed patches of $H$. deflexa for $\sim 40$ hours total to document visitation by pollinators. I found the species to be visited almost exclusively by bumblebees (Bombus spp.), including the endangered B. terricola. I also noticed that spur length decreased from the first and last flowers on a plant and I quantified this change in 16 marked individuals. Last, I found that changes in spur length coincided with reductions in visitation by bumblebees. This work does not determine whether changes in pollinator behavior are influenced by spur length. It does, however, feature some novel observations of $H$. deflexa and demonstrate the importance of flower shape in a plant-pollinator system.

Temporal changes in energy metabolites in the brain of Danio rerio following exposure to hypoxia and high environmental ammonia

Lauren E. Berrington [1], Tamara Rodela [1]

[1] Department of Biology, St. Francis Xavier University, Antigonish, Nova Scotia, Canada, B2G 2W5

Low ambient oxygen (hypoxia) and high environmental ammonia (HEA) are two environmentally relevant stressors that occur sequentially or simultaneously within aquatic environments. Previous work has shown that zebrafish acclimated to ammonia have increased tolerance to hypoxia, and acclimation to hypoxia enhances ammonia tolerance. While the physiological responses of hypoxia exposed fish are well characterized and show a disruption to energy metabolism, measurements in HEA exposed fish have not been investigated. However, the mammalian literature shows a similar disruption in energy metabolism following ammonia accumulation in liver dysfunction. We hypothesize that hypoxia and HEA exposure inhibits metabolic pathways, impairing aerobic energy metabolism. The objective of study was to examine whether HEA and hypoxia disrupts high energy metabolites, specifically $\mathrm{NAD}^{+}$and $\mathrm{NADH}$. Zebrafish (Danio rerio) were exposed to hypoxia, HEA, and simultaneous hypoxia and HEA. Fish were euthanized at $0,2,4,8,16,32$, and $64 \mathrm{~h}$ throughout each exposure and brain tissue was sampled. Cerebral NAD ${ }^{+}$and NADH levels were assayed spectrophotometrically. Preliminary data indicate temporal differences in $\mathrm{NAD}^{+}: \mathrm{NADH}$ ratios between treatment groups, with increases in ratios occurring at $4 \mathrm{~h}$ in the hypoxia exposed group; 32, $64 \mathrm{~h}$ in the HEA group, and $64 \mathrm{~h}$ in the combined HEA and hypoxia group. Impaired NAD ${ }^{+}$NADH ratios are indicative of impaired energy metabolism after both hypoxia and HEA exposure. These results identify similar responses in zebrafish to hypoxia and HEA exposure and will allow us to target future research on how stressor acclimation may modulate metabolic processes to enhance tolerance to sequential exposure to multiple stressors.

The effect of endocannabinoid and nitric oxide interactions on anxiety-like behaviour in the rat Hailey V. Burns, BSc Student [1], Karen M. Crosby, PhD [1]

[1] Department of Biology, Mount Allison University, Sackville, New Brunswick, Canada E4L 1E2

Anxiety disorders are a major psychological health concern in today's society; however, current treatments include pharmaceutical medications that target GABA and serotonin neurotransmitters and are known to cause adverse effects. The release of other neurotransmitters in areas of the brain associated with anxiety, notably the limbic system, have been shown to be regulated by endocannabinoids (eCBs) and nitric oxide (NO). The relationship between eCBs, NO and anxiety is complex, and the neuronal mechanisms remain unclear. Thus, the purpose of this study was to further investigate the interactions between eCBs and $\mathrm{NO}$ in young rats. We hypothesized that eCBs and NO will interact to regulate anxiety behaviours in rats. In order to investigate this hypothesis, juvenile male Sprague-Dawley rats were placed into one of the following treatment groups: 1) vehicle (control, 30-minute restraint), 2) URB597 (fatty acid amide hydrolase inhibitor, 30- 
UNDERGRADUATE RESEARCH IN NATURAL AND CLINICAL SCIENCE AND TECHNOLOGY (URNCST) JOURNAL Read more URNCST Journal articles and submit your own today at: https://www.urncst.com

minute restraint), 3) L-NAME (blocks NO synthesis, 30-minute restraint), 4) URB597 + L-NAME (30-minute restraint), 5) SR141716 + URB597 (cannabinoid $1\left(\mathrm{CB}_{1}\right)$ receptor antagonist, 30-minute restraint), 6) vehicle (no restraint) or 7) URB597 (no restraint) and their anxiety was tested using the elevated plus-maze test. There were no statistically significant differences observed between both vehicle and URB597 without restraint, or vehicle with and without restraint. Each drug treatment that contained a restraint period significantly decreased open arm time in the maze, reflecting anti-anxiety behaviour. These findings suggest that eCBs and NO may have anxiogenic-like effects in which $\mathrm{CB}_{1}$ receptors are not solely involved.

The genetic population structure of rainbow trout (Oncorhynchus mykiss) and brown trout (Salmo trutta) in new brunswick river systems

Jagger N. Watters-Gray, BSc Student [1], Scott A. Pavey, PhD [2,3]

[1] Department of Biological Sciences, University of New Brunswick, Saint John, New Brunswick, Canada E2L 4L5

[2] Department of Biological Sciences, University of New Brunswick, Saint John, New Brunswick, Canada E2L 4L5

[3] Canadian Rivers Institute, University of New Brunswick, Saint John, New Brunswick, Canada E2L 4L5

Rainbow trout and brown trout are cold-water salmonids that, through stocking in the 1900s, have become naturalized in New Brunswick and threaten native salmonids through resource competition. To inform management and explore the genetics of populations formed via stocking and aquaculture escapes, the genetic structure of rainbow and brown trout populations was assessed using the mitochondrial DNA control region. To achieve this study's objective, 205 brown trout and 137 rainbow trout were sampled across their population range. The control region of each individual was sequenced, and genetic structure was assessed using population pairwise $\mathrm{F}_{\mathrm{ST}}$. The undifferentiated genetic structure of rainbow trout supports panmixia, except two populations above a semi-permeable barrier (a Dam) which displayed significant structuring $(P<0.05)$. The genetic structuring of brown trout was obscured by low genetic variation; however, significant structuring of one population $(P<0.0001)$ suggests reproductive isolation. The genetic similarity of rainbow trout below the Dam is likely explained by recent (2004) establishment from a single source population, large effective population sizes, and gene flow. Differentiated genetic structure of rainbow trout above the Dam suggests genetic drift and partial reproductive isolation. Low genetic variation of brown trout suggests stocking from a single genetic origin, except one population that displayed high genetic variation and proposes stocking from multiple genetic origins. As the first population genetics assessment, this study successfully assessed the genetic structure of rainbow and brown trout in New Brunswick, providing a foundation for future work on the genetics of these species.

Fusarium head blight and deoxynivalenol from barley in the Maritime Provinces Emma Halliday, BSc Student [1]

[1]Department of Biology, Saint Mary’s University, Halifax, Nova Scotia, Canada B3H 3 C3

Fusarium head blight (FHB) is an economically important disease affecting barley worldwide causing both yield loss and contamination of grain with mycotoxins such as deoxynivalenol (DON). To better understand the populations of Fusarium spp. causing FHB in barley in the Maritime Provinces of Canada, seeds were collected from 36 fields from 10 regions by our partners at the Atlantic Grains Council. Seed samples were split with 100 seeds per field being surface sterilized and plated to isolate Fusarium spp. and a second sample of seeds were ground for both DNA extraction for species specific QPCR analysis and DON analysis. In total, 336 isolates were collected with $70 \%$ being identified as F. graminearum, $18 \%$ F. sporotrichoides, $7 \% \mathrm{~F}$. poae and $2 \% \mathrm{~F}$. avenaceum. DON contamination ranged from 0 to $15.6 \mathrm{ppm}$ and the number of isolates collected ranged from 0 to 54 from each field sample. Overall, Nova Scotia sites had the highest FHB levels based on DNA, isolate collection and DON while less FHB was observed in PEI and New Brunswick, but the ratios of different Fusarium spp. was similar in all provinces. Isolates showed differences in virulence on barley, but no association was observed between collection site. F. graminearum QPCR analysis correlated significantly with both DON (R2=0.92), but QPCR targeting other species did not correlate with mycotoxin or culture data. QPCR was a rapid and accurate method to quantify $F$. graminearum in barley seeds and will be utilized in future surveys. 
UNDERGRADUATE RESEARCH IN NATURAL AND CLINICAL SCIENCE AND TECHNOLOGY (URNCST) JOURNAL Read more URNCST Journal articles and submit your own today at: https://www.urncst.com

AMPing up the temperature in green frogs

Aileen Feschuk, BSc Student [1], Todd Smith, PhD [1], Russell H Easy, PhD [1]

[1] Department of Biology, Acadia University, Wolfville, Nova Scotia, Canada B4P 2R6

Antimicrobial peptides (AMPs) are small proteins secreted onto the skin of frogs that allow them to resist infection by many pathogens. The objective of this research is to determine how temperature alters AMP production in green frogs, the most abundant frog species in Nova Scotia. Epidermal mucous swabs were taken from three cohorts of six frogs after incubation at three temperatures, $4 \mathrm{C}$, typical of hibernation, $26 \mathrm{C}$, at the upper end of the thermal range of green frogs, and a control at $22 \mathrm{C}$. Then, SDS-PAGE and mass spectrometry were performed to separate and identify AMPs from these mucous swabs. Our results showed that frogs exposed to the $22 \mathrm{C}$ and $26 \mathrm{C}$ conditions had highly similar epidermal AMP proteomic profiles, whereas frogs in the $4 \mathrm{C}$ cohort had a depressed epidermal AMP proteome. Further results confirming the presence and identity of these AMPs are pending.

Plasticity of pheromone chemistry and female olfactory sensitivity in the tobacco budworm moth Heliothis virescens Kassandra K. Kelbratowski, BSc Student [1], Russell H. Easy, PhD [1], N. Kirk Hillier, PhD [1] [1] Department of Biology, Acadia University, Wolfville, Nova Scotia, Canada, B4P 2R6

Autodetection is a term used in insect pheromone communication to describe the ability of females to detect their own conspecific sex pheromone blend. The importance of autodetection to calling, spacing and other mating-related behaviour in the family Heliothinae is a recently emerging field of study, and as such the molecular mechanisms involved in the regulation of heliothine autodetection remain poorly understood. The objectives of this study were to examine the response of antennal olfactory receptors (ORs) following exposure to pheromones in female moths, and to examine if changes in antenna OR expression were related to changes in pheromone gland OR expression or pheromone composition. Individual female Heliothis virescens moths were isolated and subjected to 18-hour exposure to either the minor component of their pheromone blend, (Z)9-14:Ald, or to a hexane control. The pheromone blends of moths exposed to (Z)9-14:Ald had a slightly decreased ratio of (Z)11-16:Ald to (Z)9-14:Ald, from 5.31 to 3.83, as measured by relative amounts of both compounds measured by chromatography. The expression of OR6 was found to have increased in the antenna tissue samples, and decreased in the pheromone gland tissue samples. The results suggest that in female heliothine moths, pheromone exposure may influence OR expression on the antenna as well as in other tissues, which may subsequently influence pheromone production and related behavioral outcomes in mating.

\section{Conflicts of Interest}

The authors have no conflicts of interest to declare.

\section{Authors' Contributions}

KW: Chaired the planning committee for the 2020 Science Atlantic Aquaculture \& Fisheries and Biology conference, drafted the conference abstract booklet, and gave final approval of the version to be published.

RHE: Reviewed multiple drafts of the conference abstract booklet and made revisions.

RG: Assisted in the formatting and editing of the conference abstract booklet.

\section{Acknowledgements}

We would like to thank students and faculty of the Cape Breton University Department of Biology for their help organizing "the conference that never happened". It would have been great!

\section{Funding}

None declared.

\section{Article Information}

Managing Editor: Jeremy Y. Ng

Article Dates: Received Jul 20 20; Published Sep 0120 
UNDERGRADUATE RESEARCH IN NATURAL AND CLINICAL SCIENCE AND TECHNOLOGY (URNCST) JOURNAL

Read more URNCST Journal articles and submit your own today at: https://www.urncst.com

\section{Citation}

Please cite this article as follows:

White K, Easy RH, Gillis R. Science Atlantic 2020 Aquaculture \& Fisheries and Biology Conference. URNCST Journal. 2020 Sep 01: 4(8). https://urncst.com/index.php/urncst/article/view/196

DOI Link: https://doi.org/10.26685/urncst.196

\section{Copyright}

(C) Kellie White, Russell H. Easy, Rebecca Gillis. (2020). Published first in the Undergraduate Research in Natural and Clinical Science and Technology (URNCST) Journal. This is an open access article distributed under the terms of the Creative Commons Attribution License (https://creativecommons.org/licenses/by/4.0/), which permits unrestricted use, distribution, and reproduction in any medium, provided the original work, first published in the Undergraduate Research in Natural and Clinical Science and Technology (URNCST) Journal, is properly cited. The complete bibliographic information, a link to the original publication on http://www.urncst.com, as well as this copyright and license information must be included.

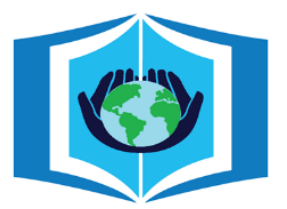

\section{URNCST Journal \\ "Research in Earnest"}

\section{Funded by the \\ Government of Canada}

Canadà̀

Do you research in earnest? Submit your next undergraduate research article to the URNCST Journal!

| Open Access | Peer-Reviewed | Rapid Turnaround Time | International |

| Broad and Multidisciplinary | Indexed | Innovative | Social Media Promoted |

Pre-submission inquiries? Send us an email at info@ urncst.com | Facebook, Twitter and LinkedIn: @URNCST

Submit YOUR manuscript today at https://www.urncst.com!
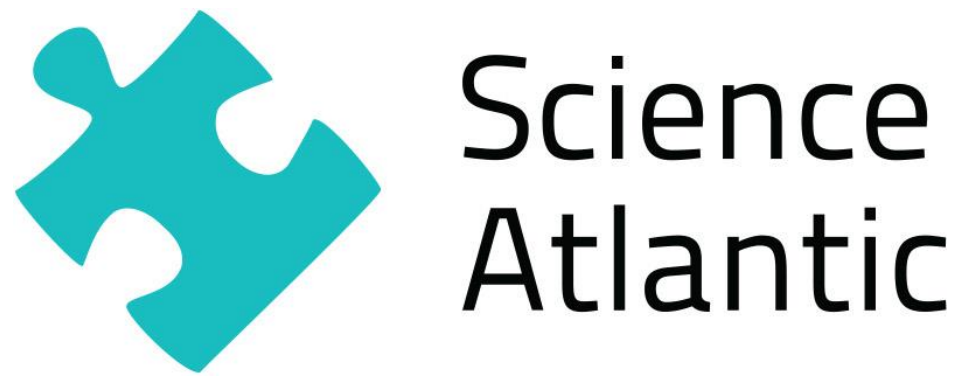

Science

Atlantique 